\title{
AKTUALISASI PENDIDIKAN ISLAM DI DALAM INSTITUSI-INSTITUSI MADRASAH TERKEMUKA ABAD KLASIK
}

\author{
Andik Wahyun Muqoyyidin ${ }^{1}$
}

\begin{abstract}
s
Madrasa as an institution of Islamic education was an idea and a brilliant achievements in the fifth century AH. With its uniqueness, during the Abbasiyah caliphate in Baghdad, madrassas became par-excellence educational institutions. After development and kuttab mosques, madrassas was growing very rapidly. Mirror at that time, the pattern of Islamic education has many variants, and almost all educational institutions when it received full support from the government in the field of finance. This was the cause of science and technology was growing rapidly. The madrassas which makes it very important function is the completeness of his room to study, known as muhadharah rooms and buildings associated with it, security for students and teachers. Similarly, in teaching and learning, teaching methods varied also be one of the aspects that are important for transferring knowledge and culture from a teacher to a student.
\end{abstract}

Keywords : Islamic Education, Institution, Madrasa, Classic

\section{A. Pendahuluan}

Perkembangan ilmu pengetahuan yang begitu pesat pada zaman klasik tidak bisa lepas dari peranan lembaga pendidikan, karena ia merupakan tempat bagi proses belajar mengajar berlangsung. Maka kajian tentang lembaga pendidikan yang menjadi sarana bagi berlangsungnya transmisi ilmu pengetahuan menjadi sangat penting (Shobahussurur, 2007: 106). Banyak sekali lembaga pendidikan yang berperan menjadi sarana pengembangan ilmu, antara lain: maktabah, kuttâb, halaqah, observatorium, rumah sakit dan klinik, dâr al-hikikmah dan dâr al-ilm, serta madrasah.

Pendidikan Islam secara kelembagaan tampak dalam berbagai bentuk yang bervariasi. Di samping lembaga yang bersifat umum seperti masjid, terdapat lembaga-lembaga yang mencerminkan kekhasan

1 Dosen Fakultas Agama Islam Universitas Pesantren Tinggi Darul ‘Ulum Jombang Komplek PP. Darul Ulum Peterongan Jombang 61481 
orientasinya. Secara umum, pada abad ke-4 Hijriyah dikenal beberapa sistem pendidikan (madaris al-tarbiyah) Islam.

Hasan Abd 'Ala, menyebut lima sistem dengan klasifikasi sebagai berikut: sistem pendidikan Mu'tazilah, sistem pendidikan Ikhwan alSafa, sistem pendidikan bercorak filsafat, sistem pendidikan bercorak tasawuf, sistem pendidikan bercorak fiqih (Suwito, et al, 2005: 200) (Maksum, 1999: 51).

Sementara itu Hasan Muhammad Hasan dan Nadiyah Muhammad Jamaluddin juga menyebutkan ada lima sistem, yaitu: sistem pendidikan bercotak teologi, sistem pendidikan bercorak Syi' ah, sistem pendidikan bercorak tasawuf, sistem pendidikan bersifat filsafat, dan sistem pendidikan bercorak fiqih (dan hadits). Institusi yang dipakai oleh masing-masing dapat digambarkan sebagai berikut:

1. Failasuf menggunakan: Dar al-Hikmah, al-Muntadiyat, Hawanit, dan Wariqin;

2. Mutasawwif menggunakan: al-Zawaya, al-Ribat, al-Masajid dan Halaqat al-Dzikr;

3. Syi'iyyin menggunakan: Dar al-Hikmah, al-Masajid, pertemuan rahasia;

4. Mutakallimin menggunakan:al-Masajid, al-Maktabat, Hawanit, al-Wariqin dan al-Muntadiyat;

5. Fuqaha (dan Ahli Hadits) menggunakan: al-Katatib, al-Madaris, al-Masajid (Maksum, 1999: 52).

Madrasah merupakan tradisi sistem pendidikan bercorak fiqh. Yang menarik adalah madrasah sebagai sebuah institusi pendidikan Islam merupakan sebuah gagasan dan prestasi yang cukup gemilang pada abad ke lima Hijriyah, demikian dikatakan al-Maqrizi dalam karyanya "Itti'adz al-Hunafa bi Akhbar al-Aimmah al-Fatimiyyin al-Khulafa" sebagaimana dikutip (Daroini, 2010: 16) beliau mengatakan bahwa "Madrasah-madrasah yang timbul dalam Islam, tidak dikenal pada masa-masa sahabat dan tabi'in, melainkan sesuatu yang baru setelah 400 tahun sesudah Hijriyah" (Badawi, 1998: 186).

Sistem di atas memiliki institusi yang khusus walaupun umumnya memanfaatkan masjid, namun demikian, madrasah dapat dianggap sebagai tradisi sistem pendidikan bercorak fiqih dan hadits, setidaknya pada masa Abbasiyah di Bagdad. Dengan kekhasan itu, pada masa 
kekhalifahan Abbasiyah di Bagdad, madrasah merupakan lembaga pendidikan par-excellence. Setelah perkembangan masjid dan kuttab, madrasah berkembang sangat pesat.

Dalam sejarah Islam dikenal banyak sekali tempat dan pusat pendidikan dengan jenis, tingkatan, dan sifatnya yang khas. Dalam buku al-Tarbiyah, Islamiyah, Nazumaha, Falsafatuha, dan Tarikuha, Ahmad Syalabi menyebutkan tempat-tempat itu sebagai berikut: al-Quttab, alQushur, hawanit al-Warraqin, Manajil al-'Ulama, al-Badriyah, dan Madrasah. Ia membagi institusi-institusi pendidikan Islam tersebut menjadi dua kelompok, yaitu kelompok sebelum madrasah dan sesudah madrasah. Madrasah yang dimaksud ialah madrasah yang dibangun oleh Nizam al-Mulk tahun $456 \mathrm{H}$. Namun demikian, ia juga mengatakan bahwa "institusi-institusi sebelum madrasah itu tetap dipakai sesuai sifat tradisionalnya sekalipun jumlah dan peminatnya sedikit" (Syalabi, 1987: 43) (Suwito, et al, 2005: 201).

Hasan Abd 'Ala, dalam (Daroini, 2010: 18) yang melakukan penelitian khusus mengenai institusi-institusi pendidikan Islam pada abad ke 4 Hijriyah, menyebutkan bahwa institusi pendidikan Islam abad itu meliputi: al-Kuttab, al-Masjid, Hawanit al-Wariqin, Manazil alUlama, al-Salun al-Adbiyah, Daur al-Kutub wa Daur al-'Ilm, dan Madrasah. Sesuai sumber di atas, Ahmad Syalabi juga menyinggung masalah Daur al-Hikmah atau sejenisnya, yang oleh Hasan Abd 'Ala dikategorikan sebagai Daur al-Kutub atau Daur al-'Ilm. Akan tetapi Syalabi tidak memasukkannya sebagai tempat pendidikan, melainkan termasuk alMaktabat. Abd 'Ala menyimpulkan bahwa "madrasah adalah institusi yang timbul pada abad ke empat Hijriyah". Dan menganggapnya sebagai "Era baru dari tahapan perkembangan institusi pendidikan Islam." Jadi menurut Abd 'Ala, madrasah sudah ada sebelum masa Nizam al-Mulk. Berangkat dari studi geneologis ini menjadi menarik untuk mengkaji lebih lanjut bagaimana aktualisasi pemikiran pendidikan Islam dalam pola pengelolaan institusi-institusi madrasah terkemuka di abad klasik tersebut.

\section{B. Institusi-Institusi Madrasah Terkemuka dan Pola Pengelolaannya}

Kajian pola pengelolaan institusi madrasah di era klasik, tidak akan lepas dari studi geneologis kemunculan madrasah itu sendiri. 
Menurut Makdisi kemunculan madrasah ditandai dengan tiga tahap, yaitu tahap masjid, tahap masjid khan, dan tahap madrasah (Makdisi, 1961: 1). Tahap masjid terutama berlangsung pada abad kedelapan dan kesembilan. Masjid yang dimaksud dalam konteks ini masjid biasa (college mosque) yang berfungsi disamping sebagai tempat ibadah bagi kaum Muslimin juga sebagai lembaga pendidikan. Di Baghdad terdapat beribu-ribu masjid college ini. Orang yang memelopori pendirian dan pengembangan masjid sebagai lembaga pendidikan adalah para penguasa seperti Abdul al-Daulah dan Di'lij al-Sajistani.

Tahap kedua adalah masjid khan, yakni masjid yang dilengkapi dengan pemondokan. Murid-murid dari berbagai belahan kota menuntut ilmu di masjid college dengan menginap di khan yang berada di sekitar masjid. Terakhir tahap ketiga adalah madrasah yang berusaha menyatukan pendidikan di masjid dan masjid khan. Kompleks madrasah terdiri dari ruang belajar, pemondokan dan masjid. Sejarah mencatat Perdana Menteri Nizam al-Mulk disebutkan sebagai seorang yang mendirikan dan mengembangkan madrasah dalam polanya yang utuh dan konkrit.

Beberapa ahli mengemukakan teori kemunculan madrasah secara historis dan sosiologis. Abd al-Majid Abd al-Futuh Badawi sebagaimana dikutip (Solichin, 2008: 206) menyatakan kelahiran madrasah dimotivasi oleh tiga motif yaitu: 1) menyebarkan pemikiran dan ajaran Sunni untuk membendung pemikiran dan ajaran Syi'ah; 2) menghasilkan guru-guru golongan Sunni yang mempunyai kemampuan untuk mengajarkan ajaran Sunni; 3) membentuk kelompok pekerja Sunni yang mempunyai peran dalam menjalankan pemerintahan khususnya dalam bidang peradilan dan manajemen (Badawi, 1998: 179).

Pola pendidikan pada masa Abbasiyah menurut Majid Irsan al-Kailani terbagi menjadi empat pola, yaitu: madrasah al-fuqahâ wa al-muhadditsîn, madrasah al-sŭfiyyah, madrasah al-falâsifah wa al-ulŭm al-thabî'iyyah, dan madrasah al-ushŭliyyîn wa 'ilm al-kalâm (Al-Kailani, 1985: 103-128).

Tradisi periodesasi Abbasiyah, pola pendidikan Islam memiliki banyak varian, dan hampir semua lembaga pendidikan waktu itu mendapatkan dukungan penuh dari pemerintah dalam bidang pendanaan. Ini yang menyebabkan hampir setiap penuntut ilmu tidak ada yang dipungut biaya. Pada akhirnya, ilmu pengetahuan 
dan teknologi berkembang pesat. Oleh sebab itu, pembacaan sketsa sejarah pendidikan Islam pada abad klasik adalah menjadi ibrah bagi generasi sekarang serta menjadi pola pembentukan pendidikan Islam masa depan (Mujab, 2012: 55).

\section{Madrasah Al-Bayhaqiyyah}

Kalau dicermati istilah madrasah dari aspek derivasi kata, maka madrasah merupakan ism makan dari kata darasa yang berarti belajar. Jadi, madrasah berarti tempat belajar bagi siswa atau mahasiswa (umat Islam). Karenanya, istilah madrasah tidak hanya diartikan sekolah dalam arti sempit, tetapi juga bisa dimaknai rumah, istana, kuttab, perpustakaan, surau, masjid, dan lain-lain. Bahkan juga seorang ibu bisa dikatakan sebagai Madrasah Pemula (Suwito, et al, 2005: 214).

Sementara menurut Makdisi dalam (Sheikh, 2013: 39) term madrasah diambil dari akar kata darasa yang mengacu pada pelajaran hukum yakni fiqih. Akan tetapi hal ini dibantah oleh Tibawi, yang menyatakan bahwa madrasah mengajarkan berbagai macam ilmu-ilmu agama selain filsafat. Hal ini ditunjukkan lewat tulisan-tulisan besar Imam Al-Ghazali dalam Ihya Ulum al-Din, yang menyatakan pentingnya mempelajari semua ilmu-ilmu agama (Tibawi, 1976: 21).

Terkait dengan sejarah munculnya madrasah, para pemerhati sejarah berbeda pendapat tentang madrasah pertama yang berdiri, namun dalam tulisan ini ada beberapa pendapat yang cukup representatif yang bisa diungkapkan tentang sejarah pertama berdirinya madrasah sebagai institusi pendidikan Islam pada masa awal. Menurut Ali alJumbulati (1994) sebelum abad ke-10 M dikatakan bahwa madrasah yang pertama berdiri adalah Madrasah al-Bayhaqiyyah di kota Nisyapur. Disebut sebagai al- Bayhaqiyyah karena ia didirikan oleh Abu Hasan al-Bayhaqi (w. 414 H). Pendapat ini diperkuat juga oleh Hasan Ibrahim Hasan (1967).

Sumber lain mengatakan bahwa Abi Ishaq (w. 406 H/1015 M) adalah orang yang pertama mendirikan madrasah di Nisyapur sebagaimana yang dikutip oleh Badawi. Azyumardi Azra menjelaskan bahwa penelitian lebih akhir yang dilakukan oleh Richard Bulliet mengungkapkan bahwa eksistensi madrasah yang lebih tua di kawasan Nisyapur, Iran, yakni madrasah Miyan Dahiya yang didirikan oleh Abu Ishaq Ibrahim ibn Mahmud. Pada sekitar tahun 400 H/1009 M terdapat Madrasah al- 
Bayhaqiyyah yang didirikan oleh Abu Hasan Ali al-Bayhaqi. Bulliet lebih menyebut 39 madrasah di wilayah Persia yang berkembang dua abad sebelum Madrasah Nizamiyyah. Hal ini juga diperkuat oleh Hasan Ibrahim Hasan dan Ali al-Jumbulati (Azra, 1994: vi).

Adapun sebab-sebab didirikannya Madrasah al-Bayhaqiyyah adalah karena masjid-masjid telah dipenuhi dengan pengajian-pengajian dari para guru yang semakin banyak, sehingga mengganggu orang yang shalat. Di samping itu, juga karena pesatnya perkembangan ilmu pengetahuan setelah semakin berkembangnya kegiatan penerjemahan buku-buku yang berbahasa asing ke dalam bahasa Arab (Suwito, et al, 2005: 106).

Adapun yang menjadikan madrasah ini paling penting fungsinya adalah kelengkapan ruangannya untuk belajar yang dikenal dengan ruangan muhadharah serta bangunan-bangunan yang berkaitan dengannya, pengamanan bagi murid-murid dan guru-gurunya.

Demikian pula, perlu dijelaskan bahwa dalam proses belajar mengajar, metode pengajaran juga merupakan salah satu aspek yang penting untuk mentransferkan pengetahuan dan kebudayaan dari seorang guru kepada pelajar. Maka metode pelajaran yang dipakai pada masa ini dapat dikelompokkan ke dalam tiga macam, yaitu lisan, hafalan, dan tulisan. Metode lisan dapat berupa dikte, ceramah, qiraah, dan diskusi. Diskusi merupakan metode yang khas dalam pendidikan Islam pada masa kini. Metode menghafal dan tulisan juga merupakan metode yang lazim dipakai dalam pembelajaran (Suwito, et al, 2005: 107).

\section{Madrasah Nizamiyyah}

Pembahasan selanjutnya akan difokuskan pada institusi pendidikan Islam (madrasah) pertama dalam arti bahwa madrasah tersebut merupakan fondasi sekaligus sebagai prototype dari kelanjutan sistem pendidikan Islam (madrasah) saat ini. Sebagaimana diketahui bahwa dalam sejarah pendidikan Islam Madrasah Nizam al-Muluk merupakan madrasah yang paling populer di kalangan ahli sejarah dan di kalangan masyarakat Islam. Madrasah Nizamiyyah didirikan oleh Nizam al-Muluk seorang perdana menteri Dinasti Salajikah pada masa pemerintahan Sultan Alp-Arslan dan Sultan Maliksyah pada abad ke-5 Hijriyah atau abad ke-11 Masehi tepatnya diresmikan pada tahun 459 H/1067 M. Para 
ulama besar mengajar di madrasah ini, antara lain Abu Ishaq al-Syirazi al-Fairuzabadi, pengarang kitab Tanbih, kitab fiqih madzhab Syafi'i. Juga Abu Hamid al-Ghazali yang menjadi guru besarnya di madrasah tersebut (Shobahussurur, 2007: 109).

Sebagai penunjukan bahwa Madrasah Nizamiyyah adalah salah satu madrasah yang menjadi model bagi madrasah-madrasah lain di seluruh daerah kekuasaan Islam dengan corak Syafi'i dapat dilihat dari dokumen wakaf Nizamiyyah yang masih terpelihara dengan baik, seperti yang dikemukakan Stanton dalam (Siswanto, 2008: 81) sebagai berikut: 1) Nizamiyyah merupakan wakaf yang disediakan untuk kepentingan penganut madzhab Syafi'i dalam fiqih dan ushul al-fiqih, 2) Harta benda yang diwakafkan kepada Nizamiyyah adalah untuk kepentingan penganut madzhab Syafi'i dalam fiqih dan ushul al-fiqih, 3) Pejabat-pejabat utama Nizamiyyah harus bermadzhab Syafi'i dalam fiqih dan ushul al-fiqih, mencakup mudarris, wa'izh dan pustakawan, 4) Nizamiyyah harus mempunyai seorang tenaga pengajar bidang kajian al-Qur'an, 5) Nizamiyyah harus mempunyai seorang tenaga pengajar bidang bahasa Arab, 6) Setiap staf menerima bagian tertentu dari penghasilan yang diperoleh dari harta wakaf Nizamiyyah (Stanton, 1994: 50).

Ada perbedaan dengan madrasah sebelumnya, mengapa Madrasah Nizamiyyah sangat populer di kalangan masyarakat Islam dan nonIslam sampai saat ini. Menurut Mehdi Nakosteen meskipun Madrasah Nizamiyyah bukan merupakan madrasah pertama dalam Islam, tetapi ia merupakan sistem madrasah pertama khusus yang didirikan oleh negara dan Sunni. Selain memiliki spirit ilmu pengetahuan yang tinggi, baik untuk tujuan politik atau agama, juga membentuk opini publik Islam Sunni ortodoks terhadap Islam Syi' ah (Nakosteen, 2003: 178).

Karena itulah indoktrinasi dan mempropagandakan madzhab Sunni, menurut Nakosteen, merupakan tujuan esensial dari Madrasah Nizamiyyah. Keberlangsungan sebuah madzhab melalui kekuatan militer bukan sebuah solusi terbaik untuk kaum Sunni saat itu. Lewat penanaman ideologi dan pendidikanlah kaum Sunni mengeliminasi pengaruh ideologi Syi'ah. Ini dilakukan karena Syi'ah secara aktif dan sistematis dalam indoktrinasi melalui pendidikan atau aktivitas pemikiran lain, disamping karena secara alamiah pendidikan akan tetap dibutuhkan setiap generasi. Generasi yang akan masuk dalam madrasah 
ini secara tidak langsung merupakan mata rantai dari eksistensi kaum Sunni (Ahmad, 1982: 232) (Nakosteen, 2003: 52-54).

Tidak dapat disangkal bahwa Madrasah Nizamiyyah telah menenggelamkan pengaruh madrasah-madrasah sebelumnya. Oleh Syalabi dalam (Muhtar, 2001: 61) dikatakan bahwa pendirian Madrasah Nizamiyyah merupakan pembatas, untuk membedakannya dengan era pendidikan Islam sebelumnya. Era baru yang dimaksud adalah adanya ketentuan konkret berkaitan dengan komponen-komponen pendidikan dan keterlibatan pemerintah dalam pengelolaan madrasah. Selanjutnya dikatakan bahwa Madrasah Nizamiyyah merupakan lembaga pendidikan resmi dan pemerintah terlibat dalam menetapkan tujuan-tujuannya, kurikulumnya, memilih guru, dan memberikan dana kepada madrasah. Dan juga ia merupakan lembaga pendidikan resmi yang menghasilkan pegawai dan karyawan-karyawan pemerintah.

Lalu, apakah Madrasah Nizamiyyah merupakan madrasah pribadi atau milik pemerintah? Makdisi menganggap bahwa Nizamiyyah merupakan madrasah pribadi. Dalam hal ini, Nizam al-Muluk seorang pribadi yang mengelola madrasah untuk tujuan-tujuan sendiri, jadi tidak ada keterlibatan pemerintah secara formal. Sementara itu, Maksum dengan analisisnya menganggap keduanya benar yaitu Madrasah Nizamiyyah merupakan milik pribadi Nizam al-Muluk, sekaligus madrasah milik pemerintah. Di lihat dari posisi, pengaruh dan pengorbanan Nizam alMuluk ada benarnya, dan di sisi lain, Madrasah Nizamiyyah merupakan kebijakan politik pemerintahan dalam mempertahankan kekuasaannya dan simpati masyarakat.

Karena itu, (terlepas dari apakah Madrasah Nizamiyyah adalah milik pribadi atau pemerintah) bahwa perkembangan Madrasah Nizamiyyah dikarenakan oleh keterpaduan dan kesamaan dalam visi antara pengelola (masyarakat) dengan pemerintah dengan tetap saling memahami dan menghargai syariat yang diyakini. Sebagai contoh; Nizam al-Muluk sebagai perdana menteri sangat fanatik terhadap Mazhab Sunni, sementara pihak pemerintah sendiri menganut paham Asy'ariyyah. Meskipun demikian, keduanya bisa berjalan dan saling menghargai karena memiliki satu visi, yaitu mempertahankan sekaligus ekspansi kekuasaan.

Selanjutnya, hal-hal yang bisa dijadikan rujukan dari sejarah perkembangan Madrasah Nizamiyyah dalam mencermati sekaligus mengaplikasikan sistem pendidikan Islam dewasa ini antara lain: 
a. Madrasah sebagai institusi pendidikan Islam dijadikan sebagai sarana atau wadah dalam menghidupkan mazhab-mazhab; Mazhab Sunni dan paham Asy'ariyyah.

b. Madrasah sebagai institusi pendidikan Islam juga dijadikan sebagai tempat untuk mengembangkan ilmu-ilmu Islam antara lain; Ilmu Fiqih, Al-Qur'an dan Tafsir, Hadits dan ilmu Hadits, Nahwu, Saraf, Bahasa Arab, dan Kesusastraan.

c. Madrasah sebagai institusi pendidikan Islam dijadikan sebagai panjang tangan untuk mempertahankan kekuasaan dan pergumulan pemikiran keagamaan. Sehingga banyak Madrasah Nizamiyyah didirikan di berbagai daerah; kota Balkh, Nisyapur, 'Isfahan, Mosul, Basrah, Tibristan, dan lain-lain.

d. Nizam al-Muluk dalam mengelola pendidikan baik sebagai pencetus ide pertama berdirinya, sekaligus sebagai bagian dari pemerintah saat itu, selalu menunjukkan kesungguhannya. Hal ini tercermin dalam kesediaan menyisihkan waktunya untuk memantau secara langsung proses pendidikan dengan mengadakan kunjungan ke Madrasah-Madrasah Nizamiyyah di berbagai kota. Bahkan ia ikut terlibat dalam menyimak dan mendengarkan kuliah-kuliah yang diberikan, dan kadang-kadang juga ikut memberikan sumbangan pemikiran di depan para pelajar di madrasah tersebut.

e. Madrasah Nizamiyyah sebagai institusi pendidikan Islam mengajarkan Al-Qur'an; membaca, menghafal dan menulis (sebagai pusat kurikulum), sastra Arab, sejarah Nabi SAW. dan berhitung serta menitikberatkan pada Mazhab Syafi'i dan tidak lupa juga teologi Asy'ariyyah. Tenaga pengajar selalu berdiri di depan ruang kelas menyajikan materi-materi kuliah, sementara pelajar mendengarkan dengan khidmat sambil mencatat. Selanjutnya diadakan dialog (antara guru dan murid) terkait dengan materimateri yang dibahas.

f. Status para pengajar ditentukan pengangkatannya oleh pemerintah.

g. Keterlibatan pemerintah tidak hanya sebatas perhatian saja, namun juga telah menyediakan alokasi dana yang cukup besar untuk keperluan fisik dan non-fisik (beasiswa bagi siswa dan uang pensiun bagi tenaga pengajar). 
h. Dan yang terakhir adalah proses pendirian Madrasah Nizamiyyah telah mendapat dukungan dari berbagai pihak; pemerintah, ulamaulama, dan masyarakat. Hal ini menunjukkan bahwa Madrasah Nizamiyyah merupakan kemauan dan keinginan bersama bukan sepihak. Di samping itu juga ia bisa dijadikan sebagai cermin dalam mencermati gambaran kondisi sosial masyarakat saat itu.

Madrasah Nizamiyyah dengan segala keunggulan dan predikat agungnya, harus diakui tidak terlepas dari kritikan dan kekurangan yang juga terdapat di dalamnya. Sebagaimana Azyumardi dengan terus terang mengatakan bahwa pada dasarnya asas-asas pengembangan ilmu pengetahuan yang untuk masa sekarang sangat dipentingkan ternyata belum diakomodir oleh sistem madrasah pada abad ke lima. Dan kalaupun itu ada, maka kemampuan para ilmuwan muslim ketika itu lebih disebabkan semangat otodidak yang luar biasa dan bukan out put dari madrasah. Sangat mungkin hal ini diakibatkan karena sistem madrasah yang cenderung bersifat doktriner dan fiqih oriented an sich (Siswanto, 2008: 84).

\section{Madrasah Al-Mustanshiriyyah}

Madrasah al-Mustanshiriyyah didirikan pada masa Khalifah AlMustanshir dari Dinasti Abbasiyah. Ia menjadikan madrasah sebagai sarana penyebaran bagi empat mazhab karenanya ia memberikan empat ruang untuk masing-masing mazhab dengan fasilitas dan dukungan yang sama. Dukungan fasilitas terhadap sekolah-sekolah ini adalah lepas dari persaingan antarmazhab karena semakin meningkatnya jumlah sekolah akan semakin besar sokongan dan dukungan dana bagi fasilitas madrasah, berikut sekolah tinggi mazhab Syi'ah dan Sunni di Islam Timur (merebak kira-kira 1050 sampai 1250) (Suwito, et al, 2005: 126).

Setelah berkuasanya Bani Saljuk yang Sunni menyingkirkan Bani Buwaihi yang Syi'i, madrasah didirikan secara besar-besaran. Para khalifah, wazir, sultan, orang-orang kaya berlomba-lomba mendirikan madrasah. Di Mesir hingga abad ke tujuh Hijriyah berdiri lebih dari 63 madrasah yang kebanyakan dibiayai dengan menggunakan harta wakaf (Fahmi, 1979 dalam Shobahussurur, 2007: 109).

Madrasah dibuat terutama untuk kajian ilmu-ilmu agama dengan penekanan bidang fiqih, hadits, tafsir. Ilmu alam tidak mendapatkan 
porsi yang proporsional dalam madrasah. Pada mulanya, madrasah biasanya dibangun untuk kepentingan madzhab fiqih tertentu dan terutama dalam rangka melawan pengaruh Syiah yang dianggap sesat oleh Ahl Sunnah. Tapi belakangan, madrasah-madrasah tertentu juga mengajarkan ilmu kealaman. Khalifah al-Mustanshir (1226-1242 M / $623-640 \mathrm{H}$ ) mengangkat dokter ahli untuk mengajar para mahasiswa di Madrasah al-Mustanshiriyyah. Dokter dan para mahasiswa itu diberi gaji dan beasiswa seperti yang diberikan kepada mereka yang menekuni bidang fiqih, hadits, dan tafsir (Syalabi, 1977: 108-109) (Shobahussurur, 2007: 109).

\section{Al-Azhar}

Sejak dulu hingga kini, Mesir bisa dibilang masih menjadi kiblat studi keislaman. Tak heran bila Mesir tetap menjadi idola sebagian besar para peminat studi ilmu-ilmu keislaman. Maklum, di negeri yang terkenal dengan Sungai Nilnya ini terdapat universitas tertua di dunia, Universitas al-Azhar (Kusmayadi, 2007: 83). Meski konstelasi politik di sana yang masih belum kondusif saat ini, namun itu tampaknya tidak mengurangi arti penting eksistensi al-Azhar.

Bermula dari Maad bin Manshur (319-365 H), khalifah ke empat Dinasti Fathimiyah berkuasa, memerintahkan salah satu panglimanya, Jauhar Al Shiqqili untuk membangun sebuah kota bernama Al Qahirah (Kairo). Setahun kemudian, dibangunlah sebuah masjid yang bernama Jami Al Qahirah. Pada masa Khalifah Aziz Billah dibangun beberapa istana di sekitar Jami Al Qahirah, yang disebut Qushur Al Zahirah, disertai beberapa taman di sekitarnya. Sehingga para warga mulai menyebut Jami Al Qahirah dengan sebutan Jami al-Azhar, yang berasal dari kata zahra. Artinya berkilauan, dikarenakan pengaruh dari kilauan istana dan indahnya taman di sekitarnya (Thoriq, 2007: 85).

Di kemudian hari masjid ini berkembang menjadi sebuah universitas besar pada akhir masa al-Mu'iz li Dinillah al-Fatimi pada bulan Shafar $365 \mathrm{H}$ (Oktober $975 \mathrm{M}$ ) yang sampai sekarang masih berdiri megah. Nama al-Azhar diambil dari al-Zahra, julukan Fatimah, putri Nabi Muhammad SAW dan istri Ali ibn Abi Thalib, imam pertama Syi'ah (Yatim, 1998: 282).

Masjid al-Azhar selesai dibangun pada tahun 361 H (972 M), merupakan masjid pertama di Kairo dan masjid keempat di Mesir, 
setelah Masjid 'Amr ibn 'Ash, Masjid 'Askar, dan Masjid Ahmad ibn Thulun. Hal ini merupakan usaha dari Dinasti Fathimiyah untuk menyebarkan paham Syi'ah.

Al-Azhar dan kota Kairo merupakan bukti monumental sebagai produk peradaban Islam di Mesir yang tetap eksis sampai saat ini. Kata al-Jami'ah yang diterjemahkan universitas berawal dari nama sebuah Masjid Jami' al-Azhar. Fenomena ini menunjukkan peradaban yang sangat maju, karena fungsi masjid tidak hanya tempat shalat an sich sebagaimana yang dikonotasikan oleh mayoritas umat Islam saat ini, tetapi difungsikan lebih luas lagi.

Pada awalnya al-Azhar bukanlah sebuah perguruan tinggi atau sebagai lembaga pendidikan formal, melainkan hanya sebagai masjid yang oleh Khalifah Fathimiyah dijadikan sebagai pusat untuk menyebarkan dakwah mereka. Pada waktu yang sama dibangun pula istana khalifah sebagai tempat untuk mengoordinasi dakwah dan membantu cara-cara penyebarannya. Pada masa ini intervensi pemerintah terhadap al-Azhar sangat besar, seperti seorang guru tidak boleh mengajar, sebelum mendapat izin dari khalifah. Karena seorang guru yang mengajar di al-Azhar, biasanya diangkat oleh khalifah.

Pada masa Fathimiyah, materi pelajaran yang diberikan di al-Azhar, di samping tentang ke-Fathimiyah-an, juga dipelajari ilmu-ilmu naqliyah dan aqliyah, antara lain: Fiqih, Hadits, Tafsir, Nahwu, Ilmu Tafsir, Ilmu Qira'at, Ilmu Hadits, dan Ilmu Kalam. Di antara ulama yang turut belajar di al-Azhar pada masa ini adalah:

a. Hasan ibn Ibrahim, yang lebih dikenal dengan Ibnu Zulaq (wafat tahun $387 \mathrm{H}$ ). Karena kecerdasannya, ia diberi penghargaan untuk menjadi tenaga pengajar di al-Azhar. Di antara karya-karyanya adalah: Kitab Fadhailu Mishr, Kitab Qudhatu Mishr, Kitab al-'Uyun $a l-D a^{\prime} j$.

b. Al-Amir al-Mukhtar 'Izzul Mulk Muhammad bin Abdullah (wafat tahun $450 \mathrm{H}$ ). Ia seorang pakar dalam bidang politik, administrasi, dan sejarah. Di antara karyanya adalah kitab al-Tarikh al-Kabir, yang dikenal dengan Tarikh Mishr.

c. Abu Abdillah al-Qudha'i (wafat tahun $454 \mathrm{H}$ ).

d. Abu Ali Muhammad bin al-Hasan bin al-Haitsam. Ia ilmuwan dalam bidang teknik, filsafat, dan matematika. Ia wafat di Kiro pada tahun $436 \mathrm{H}$. 
Pada masa ini muncul pula Ya'qub bin Kalas, seorang Menteri Khalifah al-Aziz Billah, ia termasuk ulama dakwah Fathimiyah yang mempunyai pengaruh cukup besar dalam membangkitkan pemikiran di Mesir. Ia juga memiliki kelebihan atau prestasi dalam studi fiqih aliran Fathimiyah dan telah mengarang beberapa kitab, di antaranya Kitab dalam Ilmu Fiqih. Kitab ini mencakup apa yang pernah ia dapat dari al-Muiz Lidinillah dan al-Aziz, di dalamnya juga telah mencakup Fiqih Ismailiyah.

Ya'qub bin Kalas pernah pula mengajukan kepada Khalifah al-Aziz, bahwa Jami al-Azhar tidak hanya terbatas untuk mendirikan shalat dan penyebaran dakwah Fathimiyah, tetapi dijadikan sebagai lembaga pendidikan. Tidak lama kemudian akhirnya muncul pemikiran tentang studi di Jami al-Azhar pada akhir masa al-Mu'iz Lidinillah al-Fatimi pada bulan Shafar $365 \mathrm{H}$ (Oktober $975 \mathrm{M}$ ).

Ketika itu duduk sebagai pengajar Abu Hasan Ali bin Nu'man al-Maghribi di Jami al-Azhar. Ia mengajarkan sebuah kitab al-Iqtishar karya ayahnya sendiri. Kitab ini berisi masalah-masalah Fiqhhiyyah yang berpegang kepada Imam Ahlu al-Bait. Ini merupakan kelompok studi pertama di Jami al-Azhar. Selain Abu Hasan Ali bin Nu'man alMaghribi, saudara kandungnya yang bernama Abu Abdillah Muhammad bin $\mathrm{Nu}^{\prime}$ man pada tahun $385 \mathrm{H}$ turut pula membantu mengajarkan ilmu-ilmu ahlu al-Bait.

Selanjutnya menurut Jamaluddin Surur, bahwa al-Azhar telah menduduki posisi untuk membangkitkan kehidupan peradaban Mesir terutama hal-hal yang berkaitan dengan dakwah Fathimiyah sejak masa Khalifah al-Aziz Billah. Pada masa itu umat manusia mulai bangkit semangatnya untuk mempelajari ilmu-ilmu munadzarah dan mengkaji Fiqih Syi'ah. Jami al-Azhar saat itu telah menjadi pusat ilmu pengetahuan dengan membawa misi menyebarluaskan dakwah Fathimiyah sampai dibangunnya Jami al-Hakim bi Amirillah. Sistem halaqah-halaqah yang ada saat itu merupakan dasar studi di al-Azhar.

Pada masa Khalifah Al Hakim bin Amrillah dimulailah gerakan wakaf untuk al-Azhar. Para khalifah setelahnya serta para dermawan ramai-ramai mewakafkan kekayaannya kepada al-Azhar, hingga konon kabarnya, nilai wakaf itu mencapai sepertiga kekayaan Mesir. Dari wakaf inilah roda al-Azhar terus berputar, baik untuk menghidupi para pelajarnya maupun membangun asrama hingga saat ini (Thoriq, 2007: 85). 
Setelah Daulat Fathimiyah jatuh ke tangan Shalahuddin al-Ayyubi pada tahun $567 \mathrm{H}(1171 \mathrm{M})$, maka ia mengambil kebijakan baru untuk menghilangkan aliran Syi'ah yang telah tumbuh dan berkembang sekian lama. Terutama melalui sarana al-Azhar untuk digantinya dengan aliran Sunni. Beberapa peristiwa penting yang terjadi pada masa Shalahuddin al-Ayyubi adalah:

a. Pembekuan kegiatan khutbah di al-Azhar selama hampir seratus tahun, yaitu sejak tahun $567 \mathrm{H}$ (1171 M) sampai masa Sultan alMamluki al-Dzahir pada tahun 665 H (1266 M).

b. Melakukan renovasi pembangunan al-Azhar oleh Amir Edmir dan Sultan Berbes atau Sultan al-Dzohir Berbes.

c. Al-Azhar menjadi pusat studi Islam yang amat penting, terutama ketika Kairo menjadi kiblat bagi para ulama, fuqaha, dan mahasiswa.

Hasanain Rabi' berpendapat bahwa pada abad ke-9 H (abad XV M) merupakan masa kejayaan bagi al-Azhar, karena pada saat itu al-Azhar menempati tempat tertinggi di antara madrasah-madrasah dan perguruan tinggi yang ada di Kairo. Ketika itu, al-Azhar sebagai induk madrasah juga sebagai perguruan tinggi terbesar yang tidak ada rivalnya di mana pun, para ulama dari berbagai negara juga datang mengunjungi al-Azhar untuk belajar.

Pada masa Mamalik, kebijakan dan perhatian pemerintah terhadap al-Azhar sangat kondusif untuk pengembangan al-Azhar sebagai sebuah perguruan tinggi. Di antaranya adalah al-Azhar banyak mendapat wakaf dari para sultan dan umara yang tujuannya adalah untuk membantu dan memelihara kemasyhuran ilmu pengetahuan di al-Azhar dan untuk kontinuitas al-Azhar sebagai pusat pergerakan ilmu pengetahuan di Mesir dan dunia Islam. Harta wakaf al-Azhar sampai saat ini masih digunakan untuk membayar gaji para dosen dan karyawannya, pemberian beasiswa kepada para pelajar dan mahasiswa, baik untuk warga negara Mesir sendiri, maupun warga negara asing, juga digunakan untuk membiayai pembangunan asrama pelajar dan mahasiswa.

Pada masa Mamalik, sistem pembelajaran di al-Azhar adalah para mahasiswa diberikan kebebasan memilih mata kuliah yang dipelajarinya, sesuai dengan disiplin ilmu yang dikuasai oleh masing-masing dosen. Setelah mahasiswa dapat menguasai disiplin ilmu yang diberikan oleh 
seorang dosen, maka ia dipersilahkan untuk memilih dosen lain untuk mempelajari mata kuliah yang berbeda. Bagi mahasiswa yang sudah menyelesaikan kuliahnya kepada seorang dosen, maka ia akan diberi syahadah (ijazah). Dalam ijazah tersebut diterangkan nama mahasiswa, nama dosen, mazhab, serta tanggal ijazah dikeluarkan.

Di antara ulama yang bertugas mengajar di al-Azhar pada masa Mamalik adalah:

a. Ali Ibn Yusuf Ibn Jarir al-Lakhmi (wafat tahun 713 H/1313 M), sebagai dosen dalam bidang penelitian.

b. Qiwamuddin al-Kirmani, sebagai dosen dalam ilmu fiqih dan ilmu qira'at.

c. Syamsuddin al-Ashbahani, sebagai dosen dalam bidang pemikiran.

d. Syarifuddin al-Zawawi al-Maliki.

e. Qunbur ibn Abdillah al-Sibziwani (wafat tahun $801 \mathrm{H}$ ), sebagai dosen dalam ilmu-ilmu aqliyah.

f. Badruddin Muhammad ibn Abi Bakar al-Dimamini (wafat tahun $827 \mathrm{H} / 1424 \mathrm{M}$ ), sebagai dosen dalam ilmu nahwu, nujum, dan fiqih.

Menurut Hasanain Rabi' bahwa pada abad ke-9 H (abad ke-15 M) merupakan masa gemilang bagi al-Azhar, karena pada saat itu alAzhar menduduki tempat tertinggi di antara madrasah-madrasah dan jamiah yang ada di Kairo pada saat itu. Ketika itu, al-Azhar sebagai induk sekolah dan sebagai Jamiah Islamiyah terbesar. Dan ulama-ulama muslimin dari berbagai negara datang dan belajar di Jami' al-Azhar.

Di antara ulama yang datang ke Mesir saat itu adalah Ibn Khaldun tahun 784 H (1382) dan sempat menuntut ilmu di al-Azhar. Ibn Khaldun pernah berkata: Jika sekiranya saya punya waktu, saya ingin lebih lama belajar di Jami al-Azhar. Pada saat itu ia sempat melakukan kontak dengan para ulama dan ahli sejarah Mesir. Dari hasil pertemuan dan kontak tersebut, dibangunlah sebuah lembaga pendidikan untuk studi sejarah.

Azyumardi Azra berpendapat, sebagai sebuah perguruan tinggi yang sudah berusia tua, al-Azhar pun mengalami pasang dan surut dalam perkembangannya. Sejak masa Dinasti Usmani (1517-1798 M) 
pamor al-Azhar mulai menurun, sehingga alasan kuat bagi penguasa pembaru seperti Muhammad Ali untuk campur tangan lebih jauh dalam pembenahan al-Azhar sejak paroan pertama abad ke-19. Kenyataan inilah yang menjadi preseden lenyapnya independensi al-Azhar sebagai lembaga akademis, yang pada gilirannya juga memengaruhi otoritas atau kewibawaannya, khususnya dalam hubungannya dengan kekuasaan politik, hingga dewasa ini (Azra, 2000: 243-244).

\section{Penutup}

Dengan beberapa paparan yang telah disebutkan penulis di atas, maka tampak jelas bahwa eksistensi madrasah pada awalnya memiliki sejarah yang panjang selama perjalanan peradaban Islam, dan berkontribusi terhadap lahirnya tradisi intelektual Islam. Ia merupakan transformasi dari pola pengelolaan institusi pendidikan Islam sebelumnya, seperti $k u t t a b$, masjid dan lain-lain. Meskipun tradisi keilmuan secara langsung tidak lahir di institusi madrasah, dikarenakan madrasah langsung dihandle oleh pemerintah, namun melalui institusi ini telah menumbuhkan kecintaan dan gairah para intelektual Islam terhadap ilmu pengetahuan. Ini terbukti dari karya-karya mereka dari berbagai bidang ilmu baik ilmu agama maupun ilmu pengetahuan (sains).

Sebab-sebab didirikannya Madrasah al-Bayhaqiyyah adalah karena masjid-masjid telah dipenuhi dengan pengajian-pengajian dari para guru yang semakin banyak, sehingga mengganggu orang yang shalat. Di samping itu, juga karena pesatnya perkembangan ilmu pengetahuan setelah semakin berkembangnya kegiatan penerjemahan buku-buku yang berbahasa asing ke dalam bahasa Arab. Kemudian institusi pendidikan Islam (madrasah) pertama dalam arti bahwa madrasah tersebut merupakan fondasi sekaligus sebagai prototype dari kelanjutan sistem pendidikan Islam (madrasah) saat ini adalah Madrasah Nizamiyyah. Madrasah Nizamiyyah didirikan oleh Nizam al-Muluk seorang perdana menteri Dinasti Salajikah pada masa pemerintahan Sultan Alp-Arslan dan Sultan Maliksyah pada abad ke-5 Hijriyah atau abad ke-11 Masehi tepatnya diresmikan pada tahun 459 H/1067 M.

Madrasah al-Mustanshiriyyah didirikan pada masa Khalifah AlMustanshir dari Dinasti Abbasiyah. Ia menjadikan madrasah sebagai sarana penyebaran bagi empat mazhab karenanya ia memberikan empat ruang untuk masing-masing mazhab dengan fasilitas dan dukungan 
yang sama. Dukungan fasilitas terhadap sekolah-sekolah ini adalah lepas dari persaingan antarmazhab karena semakin meningkatnya jumlah sekolah akan semakin besar sokongan dan dukungan dana bagi fasilitas madrasah, berikut sekolah tinggi mazhab Syi'ah dan Sunni di Islam Timur. Sementara itu, meskipun pada awalnya al-Azhar merupakan sebuah masjid, namun pada perkembangannya berubah menjadi sebuah universitas tertua di dunia, yaitu pada akhir masa alMu' iz Lidinillah al-Fatimi pada bulan Shafar tahun 365 H (Oktober 975 M). Hal ini merupakan bukti historis monumental sebagai produk riil kemajuan peradaban Islam di Mesir.

\section{DAFTAR PUSTAKA}

Ahmad, Said Mursi. 1982. Tatawwur al-Fikr al-Tarbawi. Kairo: 'Alam al-Kutub.

Al-Kailani, Majid 'Irsan. 1985. Tatawwur Mafhum al-Nazhariyyah alTarbiyyah. Beirut: Dar Ibn Katsir.

Azra, Azyumardi. 1994. Pendidikan Tinggi Islam dan Kemajuan Sains. Dalam Charles Michael Stanton, Pendidikan Tinggi dalam Islam (hlm. vi). Terjemahan oleh Afandi dan Hasan Asari. Jakarta: Logos.

Azra, Azyumardi. 2000. Pendidikan Islam Tradisi dan Modernisasi Menuju Milenium Baru. Ciputat: Logos Wacana Ilmu.

Badawi, Abd Majid Abd al-Futuh. 1998. Tarikh Al-Siyasi wa al-Fikri. Al-Manshur: Mathabi' Al-Wafa.

Daroini, Mustajib. 2010. Madrasah Nizamiyah (Studi Geneologis Madrasah Pada Islam Klasik). Manahij. Vol. III, No. 2: 16-18.

Fahmi, Asma Hasan. 1979. Sejarah dan Filsafat Pendidikan Islam. Terjemahan oleh Ibrahim Husein. Jakarta: Bulan Bintang.

Kusmayadi, Dadang. 2007. Menengok Kebesaran Al-Azhar. Suara Hidayatullah. Edisi. 03, XX Juli 2007, Jumadits Tsani 1428: 83.

Maksum. 1999. Sejarah dan Perkembangannya. Jakarta: Logos.

Muhtar, Maksum. 2001. Sejarah Pendidikan Islam. Jakarta: Logos Wacana Ilmu.

Mujab, M. 2012. Studi Konstruksi Historis Pendidikan Islam Era Klasik hingga Modern. el-Hikmah. Vol. X, No. 1: 55. 
Nakosteen, Mehdi. 2003. Kontribusi Islam atas Dunia Intelektual Barat, Deskripsi Analisis Abad Keemasan Islam. Terjemahan oleh Joko S. Kahhar dan Supriyanto Abdullah. Surabaya: Risalah Gusti.

Sheikh, Adan Saman. 2013. Islamic Education in Kenya: A Case Study of Islamic Integrated Schools in Garissa County. PhD Thesis. Kenya: The Department of Philosophy and Religious Studies, University of Nairobi.

Shobahussurur. 2007. Lembaga Pendidikan dalam Khazanah Islam Klasik: Telaah atas Proses Sejarah dan Transmisi Ilmu. TSAQAFAH. Vol. 3, No. 1: 106-109.

Solichin, Mohammad Muchlis. 2008. Pendidikan Islam Klasik (Telaah Sosio-Historis Pengembangan Kurikulum Pendidikan Islam Masa Awal Sampai Masa Pertengahan). Tadrîs. Vol. 3, No. 2: 206.

Siswanto. 2008. Kebangkitan Madrasah di Dunia Islam (Kajian SosioHistoris tentang Madrasah Nizhamiyah). Tadrîs. Vol. 3, No. 1: 81-84.

Stanton, Charles Michael. 1994. Pendidikan Tinggi dalam Islam. Terjemahan oleh Afandi dan Hasan Asari. Jakarta: Logos.

Suwito dan Fauzan. 2005. Sejarah Sosial Pendidikan Islam. Jakarta: Kencana.

Syalabi, Ahmad. 1977. Tarikh al-Tarbiyah al-Islamiyah. Kairo: al-Nahdzah al-Mishriyyah.

Syalabi, Ahmad. 1987. Al-Tarbiyah al-Islamiyah, Nuzumuha, Falsafatuha, Tarikhuha. Kairo: Maktabah al-Nahdzah al-Mishriyyah.

Thoriq. 2007. Mata Air Ilmu. Suara Hidayatullah. Edisi. 03, XX Juli 2007, Jumadits Tsani 1428: 85.

Tibawi, A. L. 1976. Arabic and Islamic Themes: Historical, Educational and Literary Studies. London, United Kingdom: Luzac \& Company Ltd.

Yatim, Badri. 1998. Sejarah Peradaban Islam. Jakarta: RajaGrafindo Persada. 